Article

\title{
Anticancer Activity of Some Ruthenium(III) Complexes with Quinolone Antibiotics: In Vitro Cytotoxicity, Cell Cycle Modulation, and Apoptosis-Inducing Properties in LoVo Colon Cancer Cell Line
}

\author{
Mirela Mihaila ${ }^{1}$, Camelia Mia Hotnog ${ }^{1}$, Marinela Bostan ${ }^{1}$, Alexandra Cristina Munteanu ${ }^{2}$, \\ Ileana Adela Vacaroiu ${ }^{3}$, Lorelei Irina Brasoveanu ${ }^{1, * \mathbb{D}}$ and Valentina Uivarosi ${ }^{2}$ (D) \\ 1 Center of Immunology, Stefan S. Nicolau Institute of Virology, Romanian Academy, 285 Mihai Bravu Ave., \\ 030304 Bucharest, Romania; mirela.mihaila@virology.ro (M.M.); camelia.hotnog@virology.ro (C.M.H.); \\ marinela.bostan@virology.ro (M.B.) \\ 2 Department of General and Inorganic Chemistry, Faculty of Pharmacy, Carol Davila University of Medicine \\ and Pharmacy, 6 Traian Vuia St., 020956 Bucharest, Romania; alexandra.ticea@umfcd.ro (A.C.M.); \\ valentina.uivarosi@umfcd.ro (V.U.) \\ 3 Department of Nephrology, Faculty of Medicine, Carol Davila University of Medicine and Pharmacy, \\ 8 Eroii Sanitari Ave., 050474 Bucharest, Romania; ileanaadela@yahoo.com \\ * Correspondence: lorelei.brasoveanu@virology.ro
}

Citation: Mihaila, M.; Hotnog, C.M.; Bostan, M.; Munteanu, A.C.; Vacaroiu, I.A.; Brasoveanu, L.I.; Uivarosi, V. Anticancer Activity of Some Ruthenium(III) Complexes with Quinolone Antibiotics: In Vitro Cytotoxicity, Cell Cycle Modulation, and Apoptosis-Inducing Properties in LoVo Colon Cancer Cell Line. Appl. Sci. 2021, 11, 8594. https://doi.org/ 10.3390/app11188594

Academic Editor: Alfonso Zambon

Received: 16 August 2021

Accepted: 14 September 2021

Published: 16 September 2021

Publisher's Note: MDPI stays neutral with regard to jurisdictional claims in published maps and institutional affiliations.

Copyright: (c) 2021 by the authors. Licensee MDPI, Basel, Switzerland. This article is an open access article distributed under the terms and conditions of the Creative Commons Attribution (CC BY) license (https:// creativecommons.org/licenses/by/ $4.0 /)$.

\begin{abstract}
Cisplatin is one of the most effective anticancer agents used to treat colon cancer, which is the third malignancy between the most common human cancers in the world, but the resistance developed represents an obstacle against the full success of chemotherapy. An emerging interest appeared in finding other metallic compounds, such as ruthenium(III) complexes, for chemotherapeutic application in cancer. Our study focused on the anticancer activity of several ruthenium $(\mathrm{Ru})$ complexes with quinolone antibiotics in colon tumor cell cultures. Real-time cell analysis and drugmediated cytotoxicity tests monitored the inhibitory effects in the drug-treated LoVo colon cancer cells. Flow cytometry assays were performed to evaluate cell cycle phases distribution and apoptotic events. The obtained results showed dose-dependent increased levels of cell lysis and induction of apoptosis in LoVo cancer cells treated with the $\mathrm{Ru}(\mathrm{III})$ complexes. In addition, data showed a major decrease in cell proliferation, since the percentages of cells distributed in the $S$ cell cycle phase diminished, and a G0/G1 cell arrest was observed. Therefore, our results strongly suggest that the newly synthesized $\mathrm{Ru}(\mathrm{III})$ complexes might play an important role in future chemotherapeutic approaches, since their activity is based on diminishing cell proliferation, induction of apoptosis, and modulation of cell cycle phases.
\end{abstract}

Keywords: ruthenium complexes; quinolones; cancer drug resistance; colon cancer; cytotoxicity; apoptosis; cell cycle

\section{Introduction}

Cancer is a major public health problem worldwide with an estimated 19.3 million new cancer cases and almost 10.0 million cancer deaths occurring in 2020. Moreover, in 2040, the global cancer burden is expected to be 28.4 million cases, a $47 \%$ rise from 2020, due to the increasing risk factors associated with globalization and a growing economy [1]. Colorectal cancer is the third malignancy between the most common human cancers in the world, and it is also among the most diagnosed cancers in the United States and Europe for both men and women, with high incidence and mortality (10\% of cancer diagnosed female patients, and 9.4\% of cancer diagnosed male patients) [1,2]. Many studies showed that cancer is a multi-step process consisting of several stages of development, such as the transformation of normal cells, tumor progression, and advanced metastasis [3], and 
it involves the loss of genomic stability that promotes the acquisition of further DNA alterations leading to cell transformation and tumor progression [4,5], aberrant progression of the cell cycle, resistance to growth inhibition, proliferation without dependence on growth factors, replication without limit, evasion of apoptosis, induction of angiogenesis, and modification of cell adhesion $[3,6,7]$.

Although many types of cancers are initially susceptible to chemotherapy, over time, they can develop drug resistance that often leads to therapeutic failure. Resistance to chemotherapy and molecularly targeted therapies is a major problem facing current cancer research [8,9], and the number of drugs that have been shown to induce resistance in cancer cell killing is rapidly increasing, possibly through the modulation of survival cell components, such as proliferative or anti-apoptotic proteins [10-12]. The mechanisms of resistance to "classical" cytotoxic chemotherapeutics and to therapies that are designed to be selective for specific molecular targets share many features, such as alterations in the drug target, activation of pro-survival pathways, and ineffective induction of cell death [13-15].

The multi-drug combination chemotherapy was established to be a successful strategy in the management of colon cancer treatment, the reason being the potential additive or synergistic tumor cytotoxicity produced. Since the discovery of the cytotoxic properties of the cisplatin, platinum-based drugs have been investigated for cancer treatment and represent some of the most widely used anticancer chemotherapeutics, but their high toxicity and chemoresistance had spun the researchers to search for other novel chemotherapeutics based on metal compounds. In addition to cisplatin ( $\mathrm{CisPt}$ ), oxaliplatin and carboplatin are some of the most effective therapeutic agents commonly used in the treatment of colorectal cancers. [16,17]. The mechanism of action of CisPt has been linked to its ability to crosslink with the purine bases on DNA, and the CisPt-DNA adducts formed might interfere with normal DNA replication and transcription and subsequently promote the activation of cellular apoptosis [18,19].

Due to their potent cytotoxicity in cancer cells, ruthenium complexes have attracted great interest and recently emerged as potential candidates to replace platinum chemotherapy [19-21]. Over the last few years, research in colon cancer treatment has been focused on finding better chemotherapeutics. Therefore, various $\mathrm{Ru}$ complexes have been obtained and intensively studied due to their proper physicochemical and biochemical properties, such as selective bioactivity as well as the ability to overcome the resistance encountered with platinum-based drugs, which is associated with low toxicity profiles [21,22].

Ruthenium (III) complexes have shown remarkable antitumor activity with various advantages over traditional platinum drugs, including potent efficacy, low toxicity, and less drug resistance. Research in this area has shown over the last decade that subtle changes in the structure often have a significant effect on the pharmacological properties of metal complexes [20,23].

In the last years, many research studies were focused on obtaining complexes with remarkable activity using quinolones molecules as ligands [24]. Quinolones represent a class of synthetic antibacterial agents that is widely prescribed for the treatment of infections in humans or for veterinary use. The bactericidal activity of these agents arises from their capacity to inhibit two bacterial key enzymes: DNA gyrase (a type II topoisomerase) and DNA topoisomerase IV [25,26].

While quinolone-based drugs were developed to inhibit the prokaryiotic DNA gyrase [27], the antineoplastic drugs have eukaryotic type II topoisomerase as their primary target [28]. Moving the activity of quinolone from antibacterial to anticancer activity [29] represents a current challenge considering the increasing resistance to chemotherapy and the severe side effects of anti-neoplastic agents.

To accomplish this goal, different synthetic strategies were approached. The first of these directions involves chemical modifications on the quinolone nucleus, either by disruption of the zwitterionic properties of the compounds (which can be achieved by modifying the $\mathrm{C} 7$ basic substituent, or the $\mathrm{C} 3$ carboxyl group, or both) or by increasing the 
number of aromatic/condensed rings [30]. The most successful example is represented by vosaroxin (formely voreloxin), which is a first-in-class anticancer quinolone derivative that inhibits topoisomerase II and induces selective double-strand breaks, G2 arrest, and apoptosis [31,32]. Vosaroxin passed Phase 2 clinical trials in acute myeloid leukemia (AML) and platinum-resistant ovarian cancer, while in a Phase III trial, the addition of vosaroxin to cytarabine offered clinical benefit to some patients with relapsed or refractory AML [33]. Vosaroxin displays some valuable pharmacokinetic properties such as the minimal metabolization and a lack of free radical production; in addition, it is not a substrate for the glycoprotein efflux pump, and its antineoplastic activity is independent of P53 function [34].

A second direction aiming to extend the scale of biological activities for a molecular entity with coordinating properties is to obtain metal complexes with selected metal ions. In this regard, a starting point could be the complexes of quinolone antibiotics with $\mathrm{Ru}$ (III) ion based on the success of the already recognized NAMI-A [35] and KP1019 [36]. So far, only few $\mathrm{Ru}(\mathrm{III})$ complexes with quinolone antibiotics were reported. In these complexes, the quinolone molecules bind to the metal ions in two ways: as monoanionic bidentate generating metal chelates or as neutral unidentate ligand through the nitrogen atom of piperazin-1-yl moiety. The chelate complex of $\mathrm{Ru}(\mathrm{III})$ with norfloxacin of general formula $\left[\mathrm{Ru}(\text { nor) })_{3}\right]$ (nor = norfloxacinate, $\mathrm{C}_{16} \mathrm{H}_{17} \mathrm{FN}_{3} \mathrm{O}_{3}{ }^{-}$) remarkably enhances the water solubility of norfloxacin and interacts with human serum albumin [37], while the chelate of ciprofloxacin $\left[\mathrm{Ru}\left(\mathrm{C}_{17} \mathrm{H}_{17} \mathrm{FN}_{3} \mathrm{O}_{3}\right)_{3}\right] \cdot 4 \mathrm{H}_{2} \mathrm{O}$ is fully water soluble and stable under physiological $\mathrm{pH}$ for at least $48 \mathrm{~h}$, and it interacts with ct-DNA [38]. The complexes of $\mathrm{Ru}(\mathrm{III})$ with unidentate ligands levofloxacin (LEV), gatifloxacin (GAT), and pipemidic acid (Pip-H: L) with formulas $\left[\mathrm{Ru}(\mathrm{LEVO})_{3}(\mathrm{Cl})_{3}\right] \cdot 8 \mathrm{H}_{2} \mathrm{O}$ [39], [ $\left.\mathrm{Ru}\left(\mathrm{GAT}-\mathrm{NH}_{4}\right)(\mathrm{Cl})_{3}\left(\mathrm{H}_{2} \mathrm{O}\right)_{2}\right]$ [40], and $\left[\mathrm{M}(\mathrm{L})_{3}(\mathrm{Cl})_{3}\right] \cdot 6 \mathrm{H}_{2} \mathrm{O}$, respectively, were prepared and physicochemically characterized [41]. The biological evaluation of the $\mathrm{Ru}(\mathrm{III})$ complex with pipemidic acid revealed antibacterial efficiency against four kinds of bacteria-G(+) (Staphylococcus epidermidis and Staphylococcus aureus) and G(-) (Klebsiella and Escherichia coli)—and inhibitory activity against the human breast cancer (MCF-7) tumor cell line [41].

During previous research studies, our group also synthesized and characterized a series of some novel ruthenium (III) complexes with mixed ligands of the type $\mathrm{RuCl}_{3} \mathrm{~L}_{2}(\mathrm{DMSO})_{m} \cdot n \mathrm{H}_{2} \mathrm{O}[42,43]$, as described in Table 1.

Table 1. Ruthenium (III) complexes with mixed ligands of the type $\mathrm{RuCl}_{3} \mathrm{~L}_{2}(\mathrm{DMSO})_{m} \cdot n \mathrm{H}_{2} \mathrm{O}$.

\begin{tabular}{|c|c|c|c|c|c|}
\hline Complex & X1 & $\mathrm{X} 2$ & R1 & $\mathbf{R} 2$ & R3 \\
\hline $\begin{array}{c}{\left[\mathrm{RuCl}_{3}(\text { pip })_{2}(\mathrm{DMSO})\right] \cdot 2 \mathrm{H}_{2} \mathrm{O}} \\
\text { (pip = pipemidic acid); } \mathrm{Ru} \text {-pip }\end{array}$ & $\mathrm{N}$ & $\mathrm{N}$ & $\mathrm{C}_{2} \mathrm{H}_{5}$ & - & $\mathrm{H}$ \\
\hline $\begin{array}{c}{\left[\mathrm{RuCl}_{3}(\mathrm{enx})_{2}(\mathrm{DMSO})\right]} \\
(\mathrm{enx}=\text { enoxacin }) ; \mathrm{Ru} \text {-enoxa }\end{array}$ & $\mathrm{N}$ & $\mathrm{C}$ & $\mathrm{C}_{2} \mathrm{H}_{5}$ & $\mathrm{~F}$ & $\mathrm{H}$ \\
\hline $\begin{array}{c}{\left[\mathrm{RuCl}_{3}(\mathrm{nf})_{2}(\mathrm{DMSO})\right] \cdot \mathrm{H}_{2} \mathrm{O}} \\
(\mathrm{nf}=\text { norfloxacin); } \mathrm{Ru}-\mathrm{nf}\end{array}$ & $\mathrm{CH}$ & $C$ & $\mathrm{C}_{2} \mathrm{H}_{5}$ & $\mathrm{~F}$ & $\mathrm{H}$ \\
\hline $\begin{array}{l}{\left[\mathrm{RuCl}_{3}(\mathrm{cp})_{2}(\mathrm{DMSO})\right] \cdot \mathrm{DMSO} \cdot 2 \mathrm{H}_{2} \mathrm{O}} \\
\quad(\mathrm{cp}=\text { ciprofloxacin }) ; \mathrm{Ru} \text {-cipro }\end{array}$ & $\mathrm{CH}$ & $\mathrm{C}$ & $\triangle$ & $\mathrm{F}$ & $\mathrm{H}$ \\
\hline $\begin{array}{c}{\left[\mathrm{RuCl}_{3}(\text { enro })_{2}(\mathrm{DMSO})\right] \cdot \mathrm{H}_{2} \mathrm{O}} \\
(\text { enro = enrofloxacin); Ru-enro }\end{array}$ & $\mathrm{CH}$ & $\mathrm{C}$ & $\Delta$ & $\mathrm{F}$ & $\mathrm{C}_{2} \mathrm{H}_{5}$ \\
\hline $\begin{array}{c}{\left[\mathrm{RuCl}_{3}(\mathrm{of})_{2}(\mathrm{DMSO})\right] \cdot \mathrm{H}_{2} \mathrm{O}} \\
\text { (of = ofloxacin); Ru-oflo }\end{array}$ & $\mathrm{CH}$ & $\mathrm{C}$ & & $\mathrm{F}$ & $\mathrm{CH}_{3}$ \\
\hline $\begin{array}{c}{\left[\mathrm{RuCl}_{3}(\mathrm{levof})_{2}(\mathrm{DMSO})\right] \cdot \mathrm{DMSO} \cdot 8 \mathrm{H}_{2} \mathrm{O}} \\
(\text { levof = levofloxacin); Ru-levo }\end{array}$ & $\mathrm{CH}$ & $\mathrm{C}$ & & $\mathrm{F}$ & $\mathrm{CH}_{3}$ \\
\hline
\end{tabular}

All these complexes display an octahedral stereochemistry with the quinolone ligand acting as monodentate, coordinated through the N4 atom of the piperazinyl ring (Figure 1). 


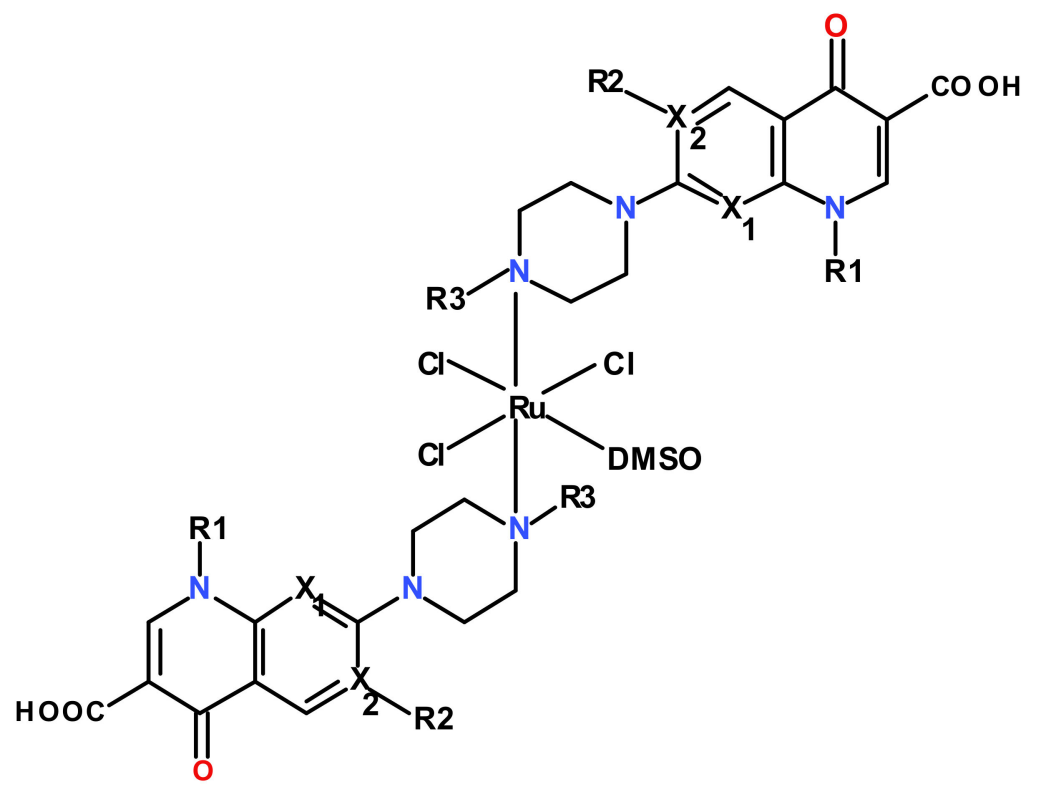

Figure 1. Structures of the investigated $\mathrm{Ru}(\mathrm{III})$ complexes with quinolones.

Our previous studies showed that these $\mathrm{Ru}(\mathrm{III})$ complexes interacted in vitro with biomolecules such as calf thymus DNA [44] and human serum transferrin [45], and they presented antimicrobial activity in vitro [46] and antitumor activity in vivo [47]. In one previous study, the fluorescence intensity of the DNA-EtBr system was registered in the absence and in the presence of increasing amounts of complexes. The competitive study revealed the quenching of the fluorescence intensity of the DNA-EtBr system for all complexes, suggesting an intercalative mode for interaction with DNA [44]. The phenomenon is not singular, since other studies performed by our research group showed that organo-metal compounds induced cell lysis and apoptosis in several human cancer cell lines [48-50].

Apoptosis or "programmed cell death", along with the cell cycle, represented important research directions addressed by our group, due to the implications that these biological processes could have in the evolution of neoplastic diseases and the therapeutic approaches in cancer. The evaluation of the apoptosis process and cell cycle phases, added by the characterization of related molecules, key regulators, in human cancer cells, was addressed by other previous in vitro studies performed by our group, which were carried out mainly in colon [7,11], renal [51], mammary [52], ovarian [53], or head and neck cells [54,55]. Moreover, due to the fact that often, the effect of cancer therapy could be amplified by combined treatments, in vitro approaches were made in testing the biological activity of several biocompounds as additional treatments to classical chemotherapy $[7,11,52,55]$. In addition, because the mode of administration of anticancer drugs and adjuvants contributes to increasing the therapeutic effect and diminishing the unwanted side effects, we studied the capacity of nanoparticles to better sensitize the tumor cells as well as modulate apoptosis and proliferation [56,57]. The last but not least research direction aimed to decipher the mechanisms underlying the drug resistance and find the means to reverse it in various cancer cell lines [7,55].

Therefore, all these together with the anticancer potential showed by $\mathrm{Ru}(\mathrm{III})$ complexes prompted us to extend our studies on the investigation of the in vitro anticancer biological activity of the $\mathrm{Ru}(\mathrm{III})$ complexes with some quinolone antibiotics in the human colon adenocarcinoma LoVo cell line, using as positive control the therapeutic drug cisplatin (CisPt). 


\section{Materials and Methods}

\subsection{Reagents}

The $\mathrm{Ru}(\mathrm{III})$ complexes studied were previously synthesized and characterized $[39,40]$. The stock solutions were prepared by dissolving the $\mathrm{Ru}(\mathrm{III})$ complexes in a minimum amount of DMSO, which was diluted in the cosolvent system $\mathrm{H}_{2} \mathrm{O}$ :Polyethyleneglycol 400 (PEG400) 3.8:6.2 (V/V) and preserved at $-20^{\circ} \mathrm{C}$.

Cisplatin (Cis-diammineplatinum(II) dichloride, DDP) was purchased from Sigma Aldrich (St. Louis, MO, USA), and stock solutions of $5 \mathrm{mM}$ were prepared as recommended, in ultrapure sterile water, and preserved at $-20^{\circ} \mathrm{C}$. Working solutions were prepared from the frozen stocks in culture medium before each experiment.

Ribonuclease A (RNase A) from bovine pancreas, propidium iodide (PI), ethylenediaminetetraacetic acid (EDTA), dimethyl sulfoxide (DMSO), and paraformaldehyde (PFA) were obtained from Sigma Aldrich (St. Louis, MO, USA). Annexin V-FITC Apoptosis Detection kit was purchased from Becton Dickinson (BD) Biosciences (Mountain View, CA, USA).

\subsection{Cell Cultures and Treatments}

The LoVo human colon cancer cell line was derived from a metastatic tumor in the left supraclavicular region of a 56-year-old male with Dukes' type C, grade IV, colorectal adenocarcinoma, and it was purchased from the American Type Culture Collection (ATCC). Cells were routinely maintained in culture in DMEM/F12 medium added with $2 \mathrm{mM}$ L-glutamine and $10 \%$ fetal calf serum in culture flasks and incubated at $37^{\circ} \mathrm{C}$ in $5 \% \mathrm{CO}_{2}$ humidified atmosphere [11]. After $24 \mathrm{~h}$, when cells achieved around $60 \%$ confluence, they were treated for various periods of time with different concentrations of $\mathrm{Ru}(\mathrm{III})$ complexes or $\mathrm{CisPt}$, as positive control. Then, cells from flasks were detached with a non-enzymatic solution of PBS/1 mM EDTA, washed twice in PBS, and immediately used for proliferation/cytotoxicity assays or evaluation of apoptotic events by flow cytometry; alternatively, cells were fixed in ice-cold ethanol/PBS (70:30) and kept until use at $4{ }^{\circ} \mathrm{C}$ for cell cycle analysis by flow-cytometry technique. Non-treated cells were used as controls throughout all experiments [11,52,55].

\subsection{Real-Time Cell Analysis (RTCA) of Drug-Treated Cells}

To analyze the proliferation profiles of treated LoVo cells, we continuously monitored cell growth by using real-time cells analysis (RTCA) assay and an xCELLigence DP-System, which allows cell-based, label-free in vitro assays and real-time monitoring of cellular processes such as cell viability and cytotoxicity [52,58]. Changes in a cell status, such as cell morphology, cell adhesion, or cell viability led to a change in cell index (CI), which is a quantitative measure of the cell number present in a well $[7,48]$. Real-time impedance data were obtained and used to generate compound-specific profiles that are dependent on the biological mechanisms of action of each $\mathrm{Ru}(\mathrm{III})$ complex. Briefly, LoVo human colon cancer cells were cultured in DMEM culture medium added by $2 \mathrm{mM}$ L-glutamine and $10 \%$ FCS, and seeded in $100 \mu \mathrm{L}$ culture medium in 16 cell E-Plates (ACEA Biosciences, San Diego, CA, USA). Growth curves started to be automatically recorded in real time on the xCELLigence System with a DP device [11]. After cells proliferated until a cellular index (CI) over 1.0, usually after $24 \mathrm{~h}$, scalar concentrations of $\mathrm{Ru}(\mathrm{III})$ complexes or CisPt were added, and growth curves were registered in real time on a computer using RTCA 2.1.2. Software [7,52,57].

\subsection{Assessment of Drug Cytotoxicity by MTS Assay}

All assays were performed in triplicate in 96-well microtiter plates with flat-bottom (Falcon), using a CellTiter 96 Aqueous One Solution Cell Proliferation Assay (Promega), which is a MTS colorimetric assay. The method is based on the ability of metabolically active cells to reduce MTS, which is a yellow tetrazolium salt to the colored formazan that is soluble in the culture medium. Briefly, $1.5 \times 10^{4}$ cells/well were cultured in $100 \mu \mathrm{L}$ for $24 \mathrm{~h}$, culture supernatants were discarded; then, cells were treated for an additional $24 \mathrm{~h}$ 
with increasing concentrations of $\mathrm{Ru}(\mathrm{III})$ complexes or CisPt. After the end of the incubation time, $20 \mu \mathrm{L}$ of reagent mixture were added in each well: (a) MTS[3-(4,5-dimethylthiazol-2yl)-5-(3-carboxymethoxy-phenyl)-2-(4-sulfophenyl)-2H-tetrazolium, inner salt] and (b) PES (phenazine ethosulfate), which has a high chemical stability, and might be combined with MTS to form a stable solution.

After adding the coloring mixture, plates were incubated for $4 \mathrm{~h}$ at $37^{\circ} \mathrm{C}$ with mild agitation every $20 \mathrm{~min}$. The color that developed during incubation was spectrophotometrically quantified at $\lambda=492 \mathrm{~nm}$, using a Dynex ELISA reader (DYNEX Technologies-MRS, USA) $[48,50,54,57]$.

The percentages of cell lysis were calculated using with the equation below, and compared to untreated cells (considered 100\% viable):

$$
\text { Cell lysis }(\%)=100-(T-B) /(U-B) \times 100
$$

where $\mathrm{T}=$ absorbance of treated cells, $\mathrm{U}=$ absorbance of untreated cells, and $\mathrm{B}=$ absorbance of culture medium (blank), for $\lambda=492 \mathrm{~nm}$.

Cell lysis data were expressed as the mean values \pm standard deviations (SD) of three different experiments. A parallel assay for the evaluation of DMSO cytotoxicity was determined in the same experimental conditions, but no cell cytotoxicity was observed for concentrations lower than $1 \%$ (data not shown).

\subsection{Apoptosis Analysis by Flow Cytometry}

The apoptosis assay was carried out using the Annexin V-FITC Apoptosis Detection Kit and the manufacturer's protocol from Becton Dickinson (BD) Biosciences. The percentages of apoptotic cells were evaluated by double staining with Annexin V-FITC/propidium iodide (PI), followed by sample analysis by flow cytometry. As negative control of the test, the unmarked cells were used [11,52]. Briefly, $1 \times 10^{5}$ cells per tube were resuspended in $100 \mu \mathrm{L}$ binding buffer, added with $5 \mu \mathrm{L}$ Annexin V/FITC and $5 \mu \mathrm{L}$ PI solution, and then incubated for $15 \mathrm{~min} / \mathrm{RT}$ at dark. Then, $400 \mu \mathrm{L}$ binding buffer were added and percentages of apoptotic events were measured by using data acquisition by flow cytometry using a FACScan or FACS CantoII cytometers (Becton Dickinson, Immunocytometry System, Mountain View, CA, USA). Evaluation of apoptotic events was performed using WinMDI 2.9 and Kaluza softwares [11,52].

\subsection{Cell Cycle Evaluation Using Flow Cytometry}

Previously, ethanol fixed cells $\left(1 \times 10^{6}\right)$ were washed twice in PBS, and cell pellets were resuspended in $350 \mu \mathrm{L}$ of PBS and then added with $50 \mu \mathrm{L}$ of $10 \mathrm{mg} / \mathrm{mL}$ RNase A ( $1 \mathrm{mg} / \mathrm{mL}$ final concentration). After $10 \mathrm{~min}$ incubation at $37^{\circ} \mathrm{C}, 100 \mu \mathrm{L}$ of $100 \mathrm{mg} / \mathrm{mL}$ PI solution were added $\left(20 \mu \mathrm{g} / \mathrm{mL}\right.$ final concentration) and further incubated at $37^{\circ} \mathrm{C}$ for $10 \mathrm{~min}$. The probes were kept in the dark at $4{ }^{\circ} \mathrm{C}$ until data acquisition by flow cytometry using a FACS CantoII flow-cytometer (Becton Dickinson (BD) Immunocytometry System, Mountain View, CA, USA). Then, cell cycle analyses were performed using ModFIT LT software to estimate the nuclear DNA content in $3 \times 10^{4}$ nuclei and progression through cell cycle phases $[11,55]$.

\subsection{Statistical Analysis}

All measurements were performed in triplicates. Statistical analyses were performed using one-way analysis of variance (ANOVA) and GraphPad Prism 7 software (GraphPad Software Inc., La Jolla, CA, USA).

\section{Results and Discussion}

\subsection{Real-Time Cell Analysis of Proliferation of LoVo Cells Treated with Ru(III) Complexes}

The xCELLigence System of Real-Time Cell Analyzer (RTCA) allows label-free and real-time monitoring of cellular processes such as cell proliferation, cytotoxicity, adhesion, viability, invasion, and migration, using electronic cell sensor array technology. Cellular 
events are monitored in real time without the incorporation of labels by measuring the electrical impedance across inter-digitated micro-electrodes integrated on the bottom of special tissue culture plates. The actual kinetic response of the cells within an assay provided important information regarding the biological status of the cell. Changes in cell status, such as cell morphology, adhesion, or viability led to a change in cell index (CI), which is a quantitative measure of the cell number present in a well [58].

The capacity of cisplatin (CisPt), a metallic anticancer drug that has been used for many years to treat various human cancers, including colon cancer, and $\mathrm{Ru}(\mathrm{III})$ complexes to inhibit cell proliferation was investigated in a LoVo colon cancer cell line in order to modulate the chemosensitivity of colon cancer cells to drug treatments and overcome the chemoresistance. Therefore, we monitored compound-induced cytotoxicity to produce continuous compound- and concentration-dependent cell impedance profiles using the xCELLigence System and LoVo cancer cell line as our in vitro model.

To assess the optimal number of cells to be used in further assays, in a first line of experiments, LoVo colon cancer cells were seeded at scalar densities from $10^{3}$ to $10^{6} /$ well in 16-well E-Plates for a dynamic monitoring of adherent cell proliferation. The cell growth curves were automatically recorded on the xCELLigence System in real time. RTCA growth curves of LoVo cells and CI values prompted us to establish the optimal cell density to be used in further experiments and choose the $15 \times 10^{3}$ cells/well for the Ry(III) compoundmediated cell cytotoxicity assays (data not shown).

LoVo cancer cells were seeded in E-plates 16 in complete culture medium $\left(1.5 \times 10^{4}\right.$ cells/well $\left./ 100 \mu \mathrm{L}\right)$, plates were put in the xCELLigence DP device and cultured at $37^{\circ} \mathrm{C}$ in a $5 \% \mathrm{CO}_{2}$ humified atmosphere. After $24 \mathrm{~h}$, cells were added by increasing concentrations of $\mathrm{Ru}(\mathrm{III})$ complexes or CisPt (from 12.5 to $200 \mu \mathrm{M}$ ), and growth curves were registered in real time on a computer by using RTCA 2.1.2. Software. Then, the cell growth, proliferation, and viability of LoVo cells were continuously monitored. Results are expressed as normalized cell index (CI) after automatic comparison between the curves of viability for treated vs. non-treated (NT) cells (Figure 2).

Some active ruthenium complexes could manifest cytotoxic action against various cancer cell lines, including colon cancer cell lines $[16,17,20]$. Therefore, we investigated the proliferative vs. cytotoxic action of $\mathrm{Ru}(\mathrm{III})$ complexes on the LoVo colon cancer cell line, and results varied depending on the type of compound, concentration, and treatment time. RTCA analysis of the LoVo cell line proliferation curves for cells treated with concentrations between 6.25 and $200 \mu \mathrm{M}$ of $\mathrm{Ru}$ (III) complexes, and normalized vs. control (the proliferation curve for untreated cells), demonstrated a pronounced cytotoxicity decrease in viability for almost all the concentrations used in the assay, mostly for 25, 50, 100, or $200 \mu \mathrm{M}$ (Figure 2).

Among the tested $\mathrm{Ru}(\mathrm{III})$ complexes, Ru-nf, Ru-oflo, and Ru-levo seem to induce the highest inhibition of LoVo cell proliferation during the first $24 \mathrm{~h}$ of treatments with 50, 100, or $200 \mu \mathrm{M}$ of drugs. Ru-pip, Ru-enro, and Ru-enoxa showed also inhibitory effects on cell proliferation, the inhibitory effect becoming stronger with increasing treatment time.

Real-time impedance data obtained were used to generate compound-dependent cell impedance profiles that are dependent on the biological mechanisms of action of each compound. The proper concentrations of compounds with cytotoxic or cytostatic potential to inhibit the growth of LoVo adherent tumor cells were further used in end-point assays such as the evaluation of cell proliferation by colorimetric MTS assay or flow-cytometry approaches to investigate both apoptosis induction and DNA progression through cell cycle phases. 


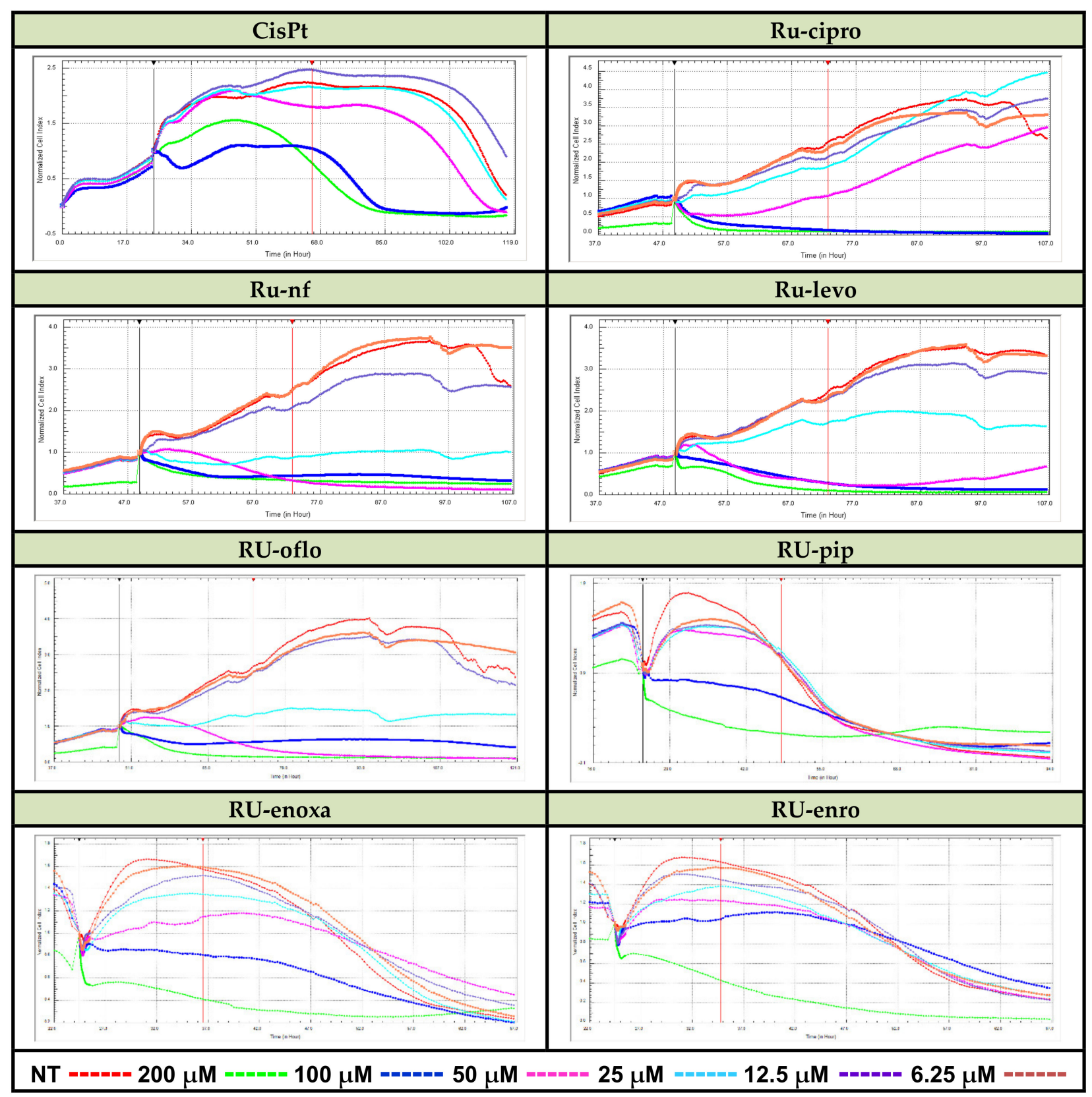

Figure 2. Real-time cell analysis of cytotoxic effects of Ru(III) complexes vs. CisPt. LoVo human colon cancer cells were treated with the reported drug concentrations in 16-well E-plates. Monitoring of Ru(III) complexes-mediated cytolysis was performed by measuring the cell index for several days using the xCELLigence DP-System and compared to CisPt-induced inhibition of proliferation vs. cell lysis.

\subsection{Cell Lysis Induced by Ru(III) Complexes Is Dose-Dependent}

After analyzing the effects of various concentrations of $\mathrm{Ru}(\mathrm{III})$ complexes on LoVo human colon cancer cell proliferation, and compared to cisplatin, in the real-time cell analysis assay using the xCELLigence DP-System, cells were subjected to an end-point, colorimetric drug-mediated cytotoxicity method. MTS assay was used in order to better assess the levels of cell lysis induced by drug treatments and discriminate between the $\mathrm{Ru}(\mathrm{III})$ complexes under study regarding their ability to kill the LoVo colon tumor cells. Increasing concentrations of $\mathrm{Ru}(\mathrm{III})$ complexes with quinolones or CisPt ranging from 3.125 to $200 \mu \mathrm{M}$ were used to treat LoVo cultured cells for $24 \mathrm{~h}$. Percentages of cell lysis induced by drug treatments in the LoVo cell line are shown in Figure 3. Untreated cells 
were used as control and considered to have $100 \%$ viability. Results were expressed as mean values of three different experiments \pm standard deviation (SD).

Analyzing the cell response to drug treatments, a cytotoxic dose-dependent effect was observed for all $\mathrm{Ru}(\mathrm{III})$ complexes and CisPt. Treatments for $24 \mathrm{~h}$ with $\mathrm{Ru}(\mathrm{III})$ complexes in cosolvents resulted in increased cell lysis rates and implicitly decreased cell viability. Thus, more than $75 \%$ of the cells were killed when the LoVo cell line was incubated either with $200 \mu \mathrm{M}$ or $100 \mu \mathrm{M}$ of Ru-nf, Ru-levo, Ru-oflo, Ru-cipro, or CisPt. Treatments with 25 or $50 \mu \mathrm{M}$ drugs induced more than $50 \%$ of cell lysis for all the $\mathrm{Ru}(\mathrm{III})$ complexes under study as well as CisPt. Even for $6.25 \mu \mathrm{M}$ or $12.5 \mu \mathrm{M}$ treatments, the percentages of cell lysis were higher than $25 \%$ for all drugs tested, while $3.125 \mu \mathrm{M}$ induced more than $14 \%$ cell lysis (Figure 3).

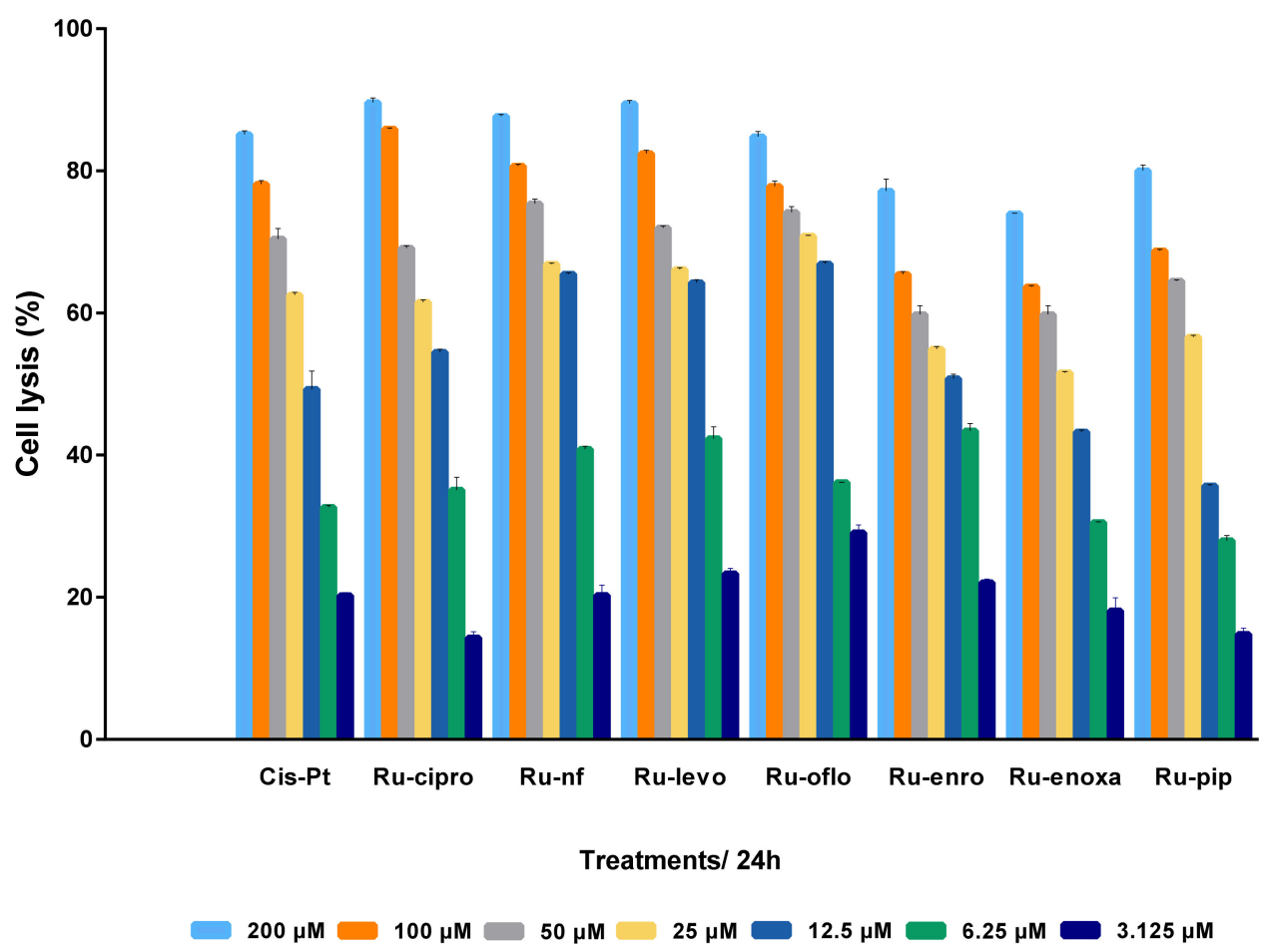

Figure 3. Antitumor effect of $\mathrm{Ru}(\mathrm{III})$ complexes against LoVo colon cancer cells. Cells lysis was induced by $24 \mathrm{~h}$ treatment with scalar concentrations of $\mathrm{Ru}(\mathrm{III})$ complexes or $\mathrm{CisPt}$, and compared to untreated control LoVo cells. Data shown are expressed as mean values \pm standard deviations (SD) of three different experiments $(n=3)$.

In addition, the inhibitory concentration values (IC) of Ru(III) complexes or CisPt were calculated using the linear regression analysis from the cytotoxicity data of each compound and for different percentages of cell lysis corresponding to drug concentrations.

Therefore, the corresponding drug concentrations required to induce the lysis of $50 \%$ (IC50), 75\% (IC75), or 90\% (IC90) of the cells were calculated when the cytotoxicity of $\mathrm{Ru}(\mathrm{III})$ complexes was assessed by MTS assay after $24 \mathrm{~h}$ of their incubation with LoVo cells compared to cisplatin as positive control (Table 2).

In terms of IC50 values, several $\mathrm{Ru}(\mathrm{III})$ complexes with quinolones displayed similar activities to the positive control, cisplatin, on LoVo cells. The best cytotoxic activity seemed to have Ru-cipro, Ru-nf, Ru-levo, and Ru-oflo since IC50, IC75, and IC90 values were the lowest (Table 2), and therefore, the toxicity profile is lower compared to cisplatin, which might allow a wide modulation of concentrations to be further used in therapeutic approaches with an improved control of the non-target cell toxicity. 
Table 2. Values ( $\mu \mathrm{M})$ of IC50, IC75, and IC90, for Ru(III) complexes and CisPt-mediated lysis.

\begin{tabular}{cccc}
\hline Compound & IC50 & IC75 & IC90 \\
\hline Ru-cipro & $27.88 \pm 3.25$ & $111.63 \pm 2.40$ & $161.87 \pm 1.89$ \\
Ru-nf & $4.70 \pm 1.36$ & $108.91 \pm 0.88$ & $171.44 \pm 2.23$ \\
Ru-levo & $7.42 \pm 1.46$ & $108.14 \pm 3.14$ & $169.15 \pm 5.84$ \\
Ru-oflo & $4.80 \pm 2.58$ & $114.89 \pm 2.31$ & $186.70 \pm 5.25$ \\
Ru-enro & $39.63 \pm 1.97$ & $165.63 \pm 7.70$ & $241.23 \pm 13.50$ \\
Ru-enoxa & $62.44 \pm 0.06$ & $174.14 \pm 2.21$ & $252.16 \pm 3.50$ \\
Ru-pip & $55.36 \pm 0.34$ & $148.70 \pm 2.86$ & $204.71 \pm 4.78$ \\
Cis-Pt & $30.7 \pm 1.13$ & $124.46 \pm 1.30$ & $180.71 \pm 1.40$ \\
\hline
\end{tabular}

IC50, IC75, and IC90 values represent the concentrations of a tested compound required to inhibit 50\%, $75 \%$, or $90 \%$ of the cell growth, with respect to the control sample (in the absence of the tested compound), and they are presented as mean $\pm \mathrm{SD}$ of three independent experiments.

The results are similar to those obtained by in vitro treatments with several other ruthenium compounds such as dinuclear $\mathrm{Ru}(\mathrm{III})$ complexes, whose effect was studied on different types of cancer cell lines, and when a reduction of cell proliferation was observed after $24 \mathrm{~h}$ of exposure to $100 \mu \mathrm{M}$ of the compounds under study [16]. In addition, some ruthenium organometallic compounds might present collateral sensitivity for cisplatinresistant cancer cells [59].

Data analysis following the MTS colorimetric assay confirms the results obtained by RTCA analysis. Thus, in subsequent end-point assays, such as apoptosis and DNA progression through cell cycle phases, LoVo cells will be treated with fixed concentrations of $10 \mu \mathrm{M}$ and $50 \mu \mathrm{M}$ of $\mathrm{Ru}(\mathrm{III})$ complexes.

\subsection{Promotion of Apoptosis by Ru(III) Complexes in LoVo-Treated Cells}

Apoptosis, known also as "programmed cell death", is a cellular "suicide" mechanism responsible for the control of the cell number in tissues and elimination of those predisposed to malignant transformation that present DNA mutations or have an aberrant cell cycle [60-63]. During tumorigenesis, apoptosis is undermined through the systematic loss of regulatory control mechanisms, finally resulting in the generation of a malignant phenotype, and resistance to chemo- and radio-therapy $[8,64,65]$. The mechanisms of apoptosis might be of great importance for carcinogenesis, tumor evasion, and have practical implications for anticancer therapy, since many anticancer drugs act during the physiological pathways of apoptosis, in the end leading to tumor cell destruction [66-70].

Along with the inhibition of cellular proliferation, apoptosis is frequently evaluated in the biological response to treatment with various chemotherapeutic agents. After automatic data acquisition from the homogenous assays of real time of the compoundspecific influence, and further of the end-point test of drug-mediated cytotoxicity, we calculated $\mathrm{IC}_{50}$ values and determined the optimal doses to be used in further end-point experiments, such as evaluation of apoptosis induction.

In order to study the potential role of $\mathrm{Ru}(\mathrm{IIII})$ complexes in the induction of apoptosis in colon cancer cells, the levels of apoptotic events were evaluated by flow cytometry techniques. LoVo colon cancer cells were cultured in complete medium for $24 \mathrm{~h}$; then, the culture medium was changed, and cells were treated for an additional $24 \mathrm{~h}$ with 10 or $50 \mu \mathrm{M}$ of $\mathrm{Ru}(\mathrm{III})$ complexes. Then, LoVo cells were detached with PBS/1 mM EDTA, sequentially washed with PBS and washing buffer, and centrifuged at $300 \times g / 5 \mathrm{~min}$. Pellets were suspended in $400 \mu \mathrm{L}$ binding buffer, and $100 \mu \mathrm{L}$ was distributed in flow tubes and stained with $5 \mu \mathrm{L}$ of Annexin-V/FITC and/or PI for $15 \mathrm{~min} / \mathrm{RT}$ in the dark [7,55]). As positive controls, cells treated with 10,25 , or $50 \mu \mathrm{M}$ cisplatin were used, while the negative control (CTRL) was represented by untreated cells. The green and red fluorescences were measured by using a FACScan flow-cytometer (BD Biosciences) after acquiring 10,000 events. Then, the acquired data were analyzed using WinMDI2.9 and Kaluza softwares, and apoptotic events were expressed as cell percentages. 
Figure 4 shows data from a significant experiment of induced apoptosis in LoVo cells by $24 \mathrm{~h}$ treatments with either $\mathrm{Ru}(\mathrm{III})$ complexes or CisPt compared to untreated cells. Total apoptosis took into account the labeled Annexin-V/FITC cells, and data are presented as histograms, the assay marker of positivity being set on non-treated cell champion.

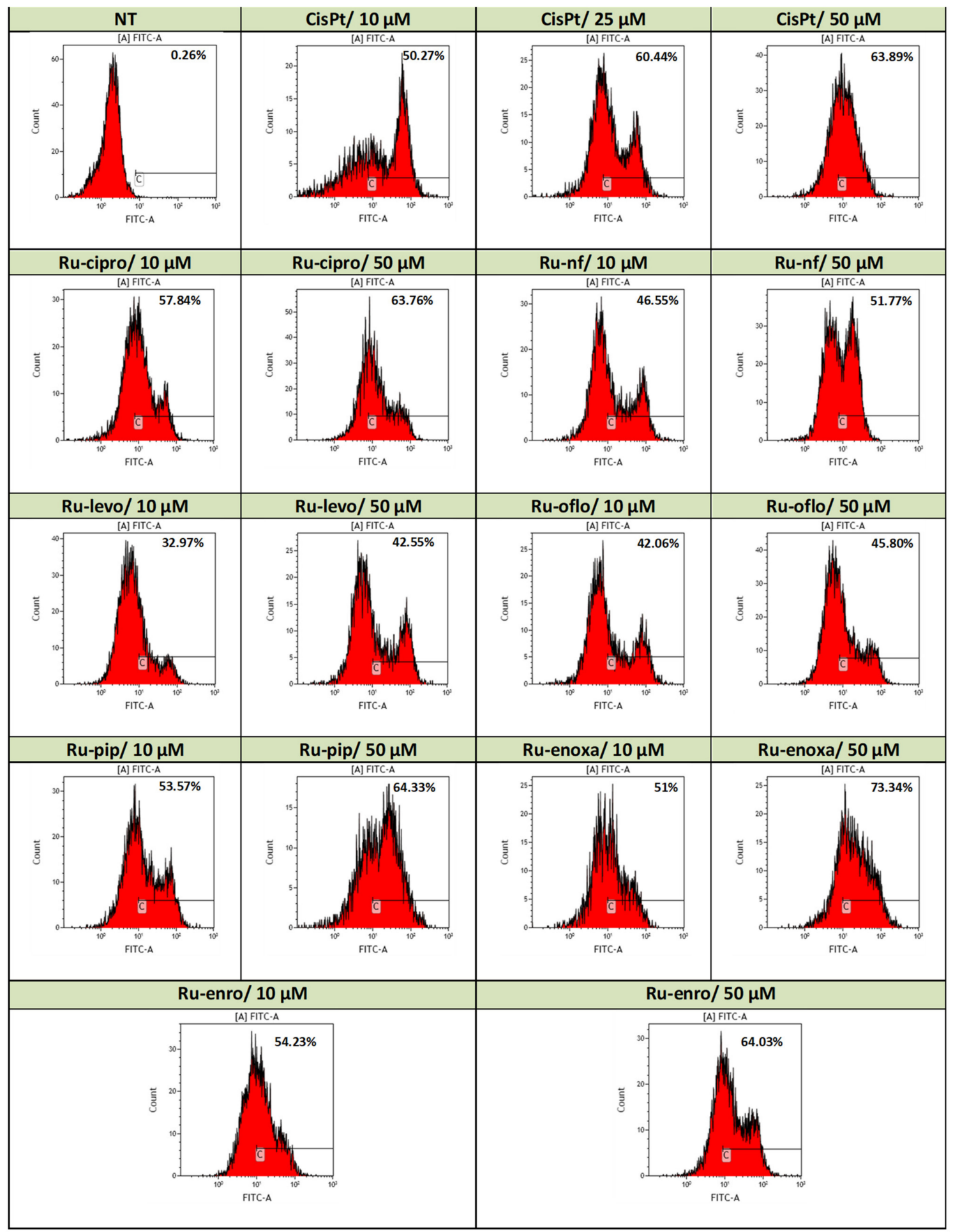

Figure 4. Induction of apoptosis in the LoVo cell line by $\mathrm{Ru}(\mathrm{III})$ complexes vs. CisPt. Effects of drug treatments on apoptosis induction in the LoVo human colon adenocarcinoma cell line were evaluated by Annexin-V/FITC and PI double-staining assay. Levels of apoptotic events were assessed by flow cytometry acquisition using a FACScan cytometer and analysis with WinMDI2.9 and Kaluza softwares. Data are presented as flow cytometry histograms. 
Annexin $\mathrm{V}$ belongs to a family of calcium-dependent phospholipid-binding proteins that bind to phosphatidylserine (PS) and allow identifying the apoptotic cells found in early and late stages, the last process preceding necrosis; propidium iodide (PI) is a dye used for assessing cell viability and the exclusion of non-viable cells that binds to double-stranded DNA but is excluded from cells with intact plasma membranes. It is used in combination with Annexin V/FITC to assess the cell viability and discriminate between apoptotic and necrotic cells; live cells do not bind Annexin or PI.

Use of $24 \mathrm{~h}$ treatments with $10 \mu \mathrm{M}$ of all $\mathrm{Ru}(\mathrm{III})$ complexes with quinolones induced higher levels of apoptosis compared to control cells with over $32 \%$ of apoptosis being found in the treated cells (Figure 4). Ru-cipro, Ru-pip, Ru-enoxa, and Ru-enro induced levels of apoptosis of $57.84 \%, 53.57 \%, 51 \%$, and $54.23 \%$, respectively, higher than the apoptotic events induced by $10 \mu \mathrm{M}$ CisPt treatment (50.27\%). The lowest apoptosis was induced by Ru-levo (32.97\%), while Ru-oflo and Ru-nf induced more than $40 \%$ of apoptosis, $42.06 \%$ and $46.55 \%$, respectively.

When drug doses of cell treatments were increased to $50 \mu \mathrm{M}$, stronger effects were observed both for $\mathrm{Ru}(\mathrm{III})$ complexes and CisPt treatments (Figure 4). Treatments with Ru-cipro, Ru-pip, and Ru enro induced levels of apoptosis comparable with those induced by CisPt treatment $(63.76 \%, 64.33 \%$, and $64.03 \%$, respectively, as compared to $63.89 \%$ ) (Figure 4$)$. The strongest effect of $73.34 \%$ apoptosis was induced by Ru-enoxa treatment. However, a high increase in the total apoptosis was also induced by Ru-nf (51.77\%), Ru-levo $(42.55 \%)$, and Ru-oflo (45.80\%) (Figure 4).

Induction of apoptosis was also achieved by cancer cell treatments with several other ruthenium (II) and (III) compounds, but levels of apoptotic events depended not only on ligands but also on the doses used and the sensitivity of the cancer cell lines tested [16,22].

\subsection{Cell Cycle Progression Changes in LoVo Cells Treated with Ru(III) Complexes}

The cell cycle is the ordered sequence of events that occur to enable DNA replication and cell division, and it can be divided in two phases (interphase and mitosis) and four stages. During these stages, the cell increases in size (gap 1/G1 stage), copies its DNA (synthesis, or S stage), prepares to divide (gap 2, or G2 stage), and then divides (mitosis or M stage). The stages G1, S, and G2 belong to the interphase, which accounts for the span between cell divisions. Some cells exit the G1 stage and enter in a resting state called G0. Based on stimulatory and inhibitory messages received by a cell, it "decides" whether it should enter into the cell cycle and divide. Regulation of the cell cycle machinery, resulting in an arrest of cells in different phases of the cell cycle, might be altered by anticancer agents, and thereby, the growth and proliferation of cancerous cells could be reduced $[16,19,71]$.

To reveal the anti-carcinogenic effects of $\mathrm{Ru}(\mathrm{III})$ complexes with quinolones that may have an inhibitory potential, cells were cultured and treated as in the experiment described above, and the end-point assay of LoVo cell progression through cell cycle phases was studied by flow cytometry. Perturbations in cell cycle progression may account for the anticarcinogenic effects. Flow cytometry assays are useful techniques that became standard tools to analyze the DNA content of cells and show the cell cycle distribution.

Therefore, non-treated control LoVo cells or cells treated either with $\mathrm{Ru}(\mathrm{III})$ complexes or CisPt were further subjected to RNase treatment, PI labeling, followed by data acquisition and analysis by flow cytometry. DNA progression through cell cycle phases is shown in Figure 5 for all drug-treated samples vs. control, which is represented by non-treated cells. The nuclear DNA content and progression through cell cycle phases were evaluated in acquired $3 \times 10^{4}$ nuclei. 


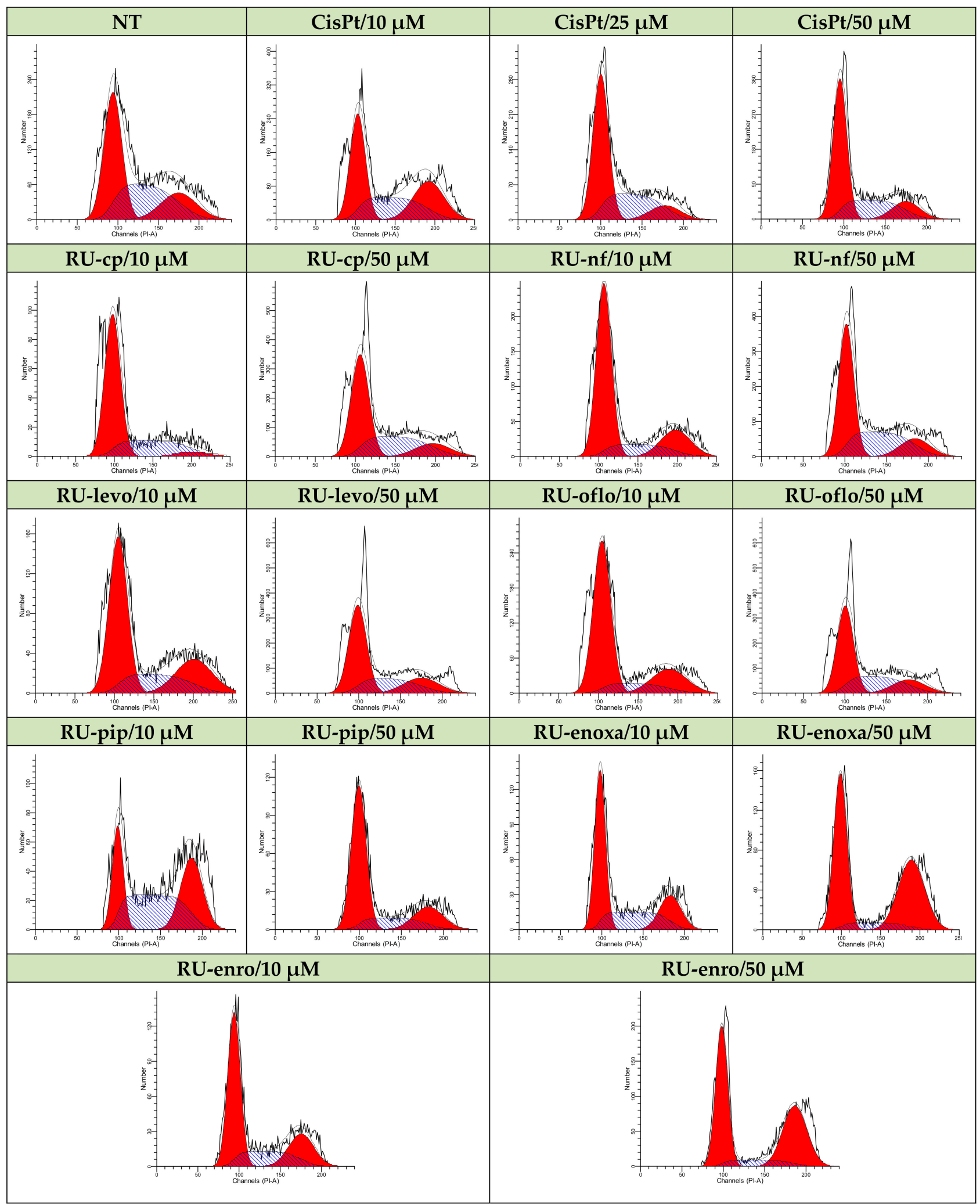

Figure 5. Modulation of LoVo cell cycle progression by $\mathrm{Ru}(\mathrm{III})$ complexes vs. CisPt. Effects of treatments with Ru(III) complexes on the modulation of cell cycle phases was studied in the LoVo human colon adenocarcinoma cell line and compared to CisPt-treated or non-treated cells. DNA progression through cell cycle phases was evaluated by PI labeling, which was followed by flow cytometry acquisition and analysis using a FACS CantoII flow-cytometer (BD Biosciences) and ModFit software. 


\section{Discussion}

The control cells displayed a cell distribution of $44.55 \%$ in $\mathrm{G} 0 / \mathrm{G} 1,36.79 \%$ in S, and $18.66 \%$ in G2M cell cycle phases. Both $10 \mu \mathrm{M}$ and $50 \mu \mathrm{M}$ CisPt treatments induced a decrease in LoVo cell proliferation, since cell distribution in the $\mathrm{S}$ phase diminished to $33.2 \%$ and $28.99 \%$, respectively, and induced a cell cycle arrest in the G0/G1 phase, where $55.84 \%$ and $56.66 \%$, respectively, of the nuclei were found (Figure 6, Table 3).

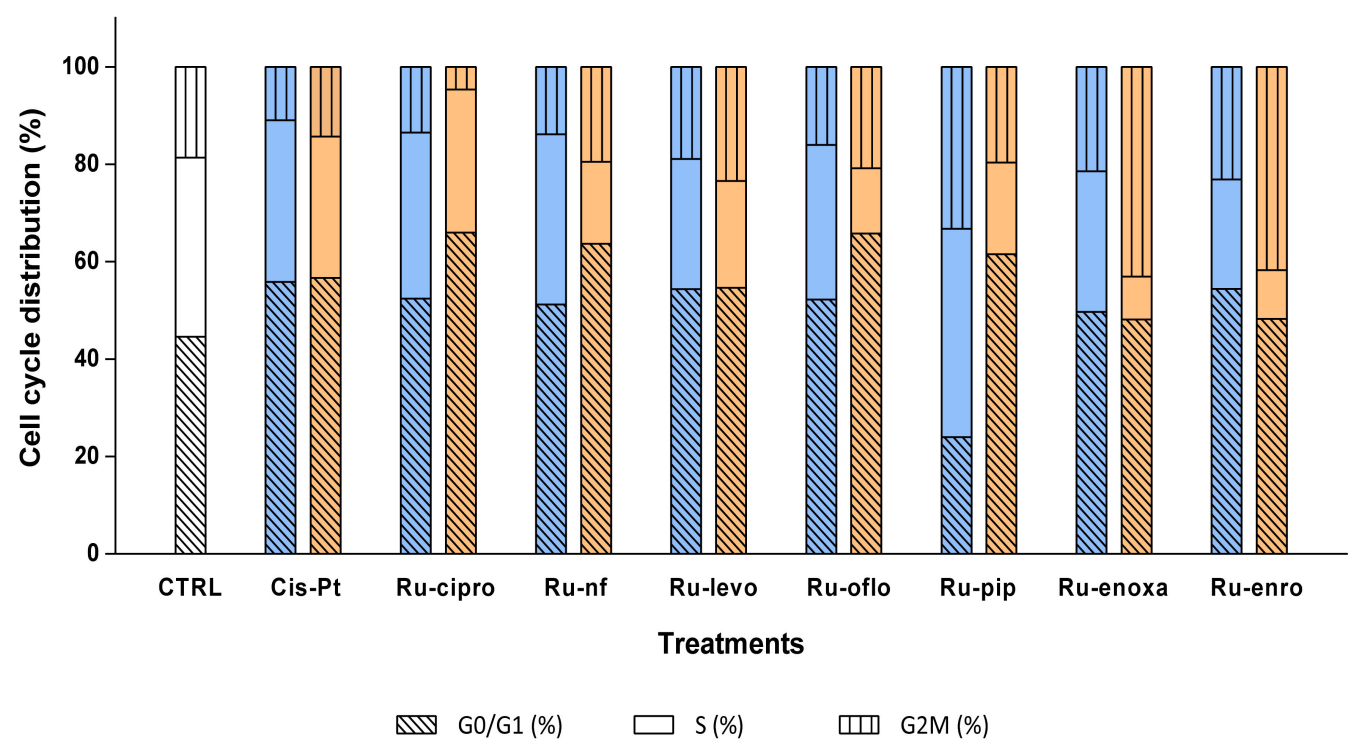

Figure 6. Effects of $\mathrm{Ru}(\mathrm{III})$ complexes on DNA progression through LoVo cell cycle phases. Cell cycle phases were analyzed in LoVo human colon adenocarcinoma cell line after cell treatments with $10 \mu \mathrm{M}(\square)$ or $50 \mu \mathrm{M}(\square) \mathrm{Ru}(\mathrm{III})$ complexes or CisPt. DNA progression through cell cycle phases was evaluated after RNase treatment and PI labeling, which was followed by flow cytometry acquisition using a FACS CantoII flow cytometer, and analysis with ModFit software. Negative control (CTRL) was represented by untreated LoVo cells.

Table 3. Evaluation of DNA progression through LoVo cell cycle phases treated either with $\mathrm{Ru}(\mathrm{III})$ complexes or CisPt.

\begin{tabular}{ccccc}
\hline \multirow{2}{*}{ Drug Treatment } & \multicolumn{3}{c}{ Cell Cycle Phases } & Proliferation Index \\
\cline { 2 - 5 } & G0/G1 (\%) & S (\%) & G2M (\%) & S+G2M (\%) \\
\hline NT & 44.55 & 36.79 & 18.66 & 55.45 \\
CisPt $(10 \mu \mathrm{M})$ & 55.84 & 33.20 & 10.96 & 44.16 \\
CisPt $(50 \mu \mathrm{M})$ & 56.66 & 28.99 & 14.35 & 43.34 \\
Ru-cipro $(10 \mu \mathrm{M})$ & 52.41 & 34.10 & 13.49 & 47.59 \\
Ru-cipro $(50 \mu \mathrm{M})$ & 66.01 & 29.29 & 4.69 & 33.98 \\
Ru-nf $(10 \mu \mathrm{M})$ & 51.19 & 34.94 & 13.88 & 48.82 \\
Ru-nf $(50 \mu \mathrm{M})$ & 63.68 & 16.77 & 19.54 & 36.31 \\
Ru-levo $(10 \mu \mathrm{M})$ & 54.38 & 26.73 & 18.89 & 45.62 \\
Ru-levo $(50 \mu \mathrm{M})$ & 54.60 & 21.99 & 23.42 & 45.41 \\
Ru-oflo $(10 \mu \mathrm{M})$ & 52.24 & 31.70 & 16.06 & 47.76 \\
Ru-oflo $(50 \mu \mathrm{M})$ & 65.76 & 13.43 & 20.81 & 34.24 \\
Ru-pip $(10 \mu \mathrm{M})$ & 23.99 & 42.74 & 33.27 & 76.01 \\
Ru-pip $(50 \mu \mathrm{M})$ & 61.51 & 18.82 & 19.67 & 38.49 \\
Ru-enoxa $(10 \mu \mathrm{M})$ & 49.70 & 28.85 & 21.45 & 50.3 \\
Ru-enoxa $(50 \mu \mathrm{M})$ & 48.11 & 8.81 & 43.09 & 51.9 \\
Ru-enro $(10 \mu \mathrm{M})$ & 54.40 & 22.47 & 23.14 & 45.61 \\
Ru-enro $(50 \mu \mathrm{M})$ & 48.28 & 9.97 & 41.75 & 51.72 \\
\hline
\end{tabular}


Cell treatments with $10 \mu \mathrm{M}$ of Ru-cipro and Ru-nf induced similar decreases in the S phase as CisPt (34.1\%, and 34.94\%), while Ru-oflo, Ru-levo, Ru-enoxa, and Ru-enro induced a decrease in cell distribution in the $\mathrm{S}$ phase between $31.7 \%$ and $22.47 \%$. At the same time, percentages of nuclei blocked in the G0/G1 phase were between $49.7 \%$ for Ru-enoxa and 54.40\% for Ru-enro (Table 3, Figure 6).

When cells were treated with $50 \mu \mathrm{M}$ of $\mathrm{Ru}(\mathrm{III})$ complexes, a higher decrease in the $S$ phase distribution was observed for all treated samples. So, the highest effect was observed for Ru-pip (18.82\%), Ru-nf (16.77\%), Ru-oflo (13.43\%), Ru-enro (9.97\%), and Ru-enoxa (8.81\%) treated cells. Treatments with $50 \mu \mathrm{M}$ of Ru-cipro, Ru-nf, Ru-oflo, and Ru-pip increased also the cell distribution of over $60 \%$ in the G0/G1 phase, while Ru-enoxa and Ru-enro induced also an increase in the G2M phase, to $43.09 \%$ and $41.75 \%$, respectively (Table 3, Figure 6).

When the proliferation indexes were calculated as the sum of the percentages of cells distributed in the S and G2M cell phases, the highest decreases were found for $50 \mu \mathrm{M}$ treatments with Ru-cipro (33.98\%), Ru-nf (36.31\%), Ru-oflo (34.24\%), and Ru-pip (38.49\%) as compared to the non-treated cells $(55.45 \%)$ or CisPt $(43.34 \%)$. In addition, $10 \mu \mathrm{M}$ treatments induced significant decreases of the proliferation index, which was mainly for Ru-cipro (47.59\%), Ru-nf (48.82\%), Ru-levo (45.62\%), Ru-oflo (47.76\%), or Ru-enro (45.61\%). Both 10 $\mu \mathrm{M}$ and $50 \mu \mathrm{M}$ of Ru-levo treatments showed similar proliferation indexes (Table 3, Figure 6).

In conclusion, increased concentrations of $\mathrm{Ru}(\mathrm{III})$ complexes seem to induce a dosedependent decrease in cell distribution found in the $S$ cell cycle phase. The results suggested that cell cycle arrest mostly took place in the G0/G1 phase and in a lower proportion also in the G2M phase, which might represent an important cause for the anti-proliferative effect of Ru(III) complexes, similar to CisPt, but hopefully less toxic.

The arrest in G0/G1 and G2-M phases are some cell cycle-regulating mechanisms related to cellular damage and, in particular, to DNA damage. In that case, DNA repair mechanisms are activated to ensure the replication of an intact DNA. When the reparation is successful, cells start again cycling; otherwise, apoptosis mechanisms are activated [16].

The results obtained during the study showed increased levels of cell lysis and apoptotic events, which are both dose-dependent in LoVo cancer cells treated with the Ru(III) complexes with quinolone antibiotics. In addition, data showed a major decrease in cell proliferation, since percentages of cells distributed in the $S$ cell cycle phase diminished, and a G0/G1 cell arrest was observed. Therefore, our results strongly suggest that the newly synthesized $\mathrm{Ru}(\mathrm{III})$ complexes might play an important role in future chemotherapeutic approaches, since their activity is based on diminishing cell proliferation, induction of apoptosis, and modulation of cell cycle phases.

\section{Conclusions}

Intrinsic (de novo) or acquired tumor cell resistance remains a major challenge for different types of chemotherapeutical approaches. Despite the recent advances in surgery, radiotherapy, and especially in chemotherapy that have led to major achievements in cancer treatment, the development of tumor cell resistance to chemotherapeutic agents is still an important problem, reducing the effectiveness of available therapies. A major goal of early approaches in individualized therapy was to develop in vitro tests to predict tumors' drug responsiveness. Since the chemosensitivity of tumors could not be predicted with high reliability, the evaluation of drug resistance is reliable independent of tumor type, test assay, and drug used in in vitro tests [72,73].

One of the most effective anticancer agents used to treat colon cancer is the platinumbased drugs, such as cisplatin, oxaliplatin, or carboplatin, but the insurgence of drug resistance and the high systemic toxicity developed are among the important obstacles against the success of chemotherapy. Ruthenium compounds have drawn great attention for their potential clinical application as anticancer drugs. Contrast data are available on their anticancer effects in colon cancer. The emerging interest appeared in developing new pharmaceutical compounds, such as $\mathrm{Ru}(\mathrm{III})$ complexes, with a high potential for 
chemotherapeutic use in cancer, and the improvement in their delivery prompted us to investigate their role in the modulation of colon cell proliferation vs. cytotoxicity, induction of apoptosis, and cell cycle regulation, in order to further find ways to improve their biological effects.

The $\mathrm{Ru}(\mathrm{III})$ complexes with quinolones developed by our group manifested a strong drug-mediated cytotoxicity against the LoVo colon cancer cell line, as assessed both by real-time cell analysis (RTCA) or end-point cytotoxicity assay, and results varied depending on the compound and concentration used. The registered RTCA proliferation curves of treated LoVo cells and the calculated IC50 values showed that Ru(III)-nf, -oflo,-levo, and -cipro were the most effective in killing colon cells at lower doses. Their toxicity profiles seemed to be lower compared to cisplatin; therefore, a wide modulation of concentrations might be further used in therapeutic approaches, and the control of non-target cell-toxicity could be improved.

Since apoptosis started to be considered as an ideal way to eliminate precancerous and/or cancer cells, and chemopreventive agents might modulate apoptosis, our experimental results obtained after evaluation of the apoptotic events induced by $\mathrm{Ru}(\mathrm{III})$ complexes with quinolones showed that treatments of colon cancer cells with the drugs under study induced dose-dependent effects, which could be useful in the management and therapy of cancer, since they proved to be at least as efficient as cisplatin. Treatments with $10 \mu \mathrm{M}$ of all $\mathrm{Ru}(\mathrm{III})$ complexes with quinolones induced over $32 \%$ of apoptosis, while Ru-cipro, Ru-pip, Ru-enoxa, and Ru-enro induced higher levels of apoptotic events than CisPt. When drug doses of cell treatments were increased to $50 \mu \mathrm{M}$, stronger effects were observed both for $\mathrm{Ru}(\mathrm{III})$ complexes and CisPt treatments, the highest apoptosis being induced by Ru-enoxa treatment (73.34\% apoptotic events).

$\mathrm{Ru}$ (III) complexes with quinolones seemed also to regulate the colon cell proliferation through cell cycle phases in a dose-dependent manner: both 10 and $50 \mu \mathrm{M}$ treatments induced a decrease in the cells found in the synthesis (S) phase; in addition, we observed an increase in the cell cycle arrest mainly in the G0/G1 phase, the highest effect being obtained for Ru-pip, Ru-nf, Ru-oflo, Ru-enro, and Ru-enoxa treated cells.

Our results, consistent with other scientific reports highlighting the cytotoxic effects of ruthenium-based drugs in colon cells, showed that $\mathrm{Ru}$ (III) complexes with quinolone antibiotics might be further used to elaborate new therapeutic approaches for future personalized cancer treatments.

Author Contributions: Conceptualization, M.M. and V.U.; methodology, M.M., C.M.H., M.B., A.C.M., L.I.B., V.U.; investigation, M.M., C.M.H., M.B., L.I.B.; resources, M.M., L.I.B., V.U.; data curation, M.M., C.M.H., M.B., A.C.M., L.I.B., V.U.; writing-original draft preparation, M.M., C.M.H., M.B., A.C.M., I.A.V., L.I.B., V.U.; writing-review and editing, M.M., C.M.H., A.C.M., L.I.B., V.U.; supervision, L.I.B. and V.U.; project administration, M.M., L.I.B. and V.U.; funding acquisition, M.M., and V.U. All authors have read and agreed to the published version of the manuscript.

Funding: This research was funded by the Ministry of Research, the Executive Unit for Financing Higher Education, Research, Development and Innovation (UEFISCDI) through grants: PCCA PN-II 136/2012, and PN-III-P2-2.1-PED-2019-5143 (Contract PED 383/2020).

Institutional Review Board Statement: Not applicable.

Informed Consent Statement: Not applicable.

Conflicts of Interest: The authors declare no conflict of interest.

\section{References}

1. Sung, H.; Ferlay, J.; Siegel, R.L.; Laversanne, M.; Soerjomataram, I.; Jemal, A.; Bray, F. Global Cancer Statistics 2020: GLOBOCAN estimates of incidence and mortality worldwide for 36 cancers in 185 countries. CA Cancer J. Clin. 2021, 71, 209-249. [CrossRef]

2. Cirri, D.; Bartoli, F.; Pratesi, A.; Baglini, E.; Barresi, E.; Marzo, T. Strategies for the improvement of metal-based chemotherapeutic treatments. Biomedicines 2021, 9, 504. [CrossRef]

3. Weber, G.F. Molecular Mechanisms of Cancer; Springer: Dordrecht, The Netherlands, 2007; Volume 39, pp. 45-54, 93-99. 
4. Solier, S.; Zhang, Y.W.; Ballestrero, A.; Pommier, Y.; Zoppoli, G. DNA damage response pathways and cell cycle checkpoints in colorectal cancer: Current concepts and future perspectives for targeted treatment. Curr. Cancer Drug Targets 2012, 12, 356-371. [CrossRef] [PubMed]

5. Temraz, S.; Mukherji, D.; Shamseddine, A. Potential targets for colorectal cancer prevention. Int. J. Mol. Sci. 2013, 14, 17279-17303. [CrossRef]

6. Jemal, A.; Siegel, R.; Ward, E.; Hao, Y.; Xu, J.; Murray, T. Cancer statistics. CA Cancer J. Clin. 2008, 58, 71-96. [CrossRef] [PubMed]

7. Hotnog, C.M.; Mihaila, M.; Puiu, L.; Botezatu, A.; Roman, V.; Popescu, I.D.; Bostan, M.; Brasoveanu, L.I. Modulation of the interplay between p53, ICAM-1 and VEGF in drug-treated LoVo colon cancer cells. Rom. Biotechnol. Lett. 2019, 24, 261-270. [CrossRef]

8. Gottesman, M.M. Mechanisms of cancer drug resistance. Annu. Rev. Med. 2002, 53, 615-627. [CrossRef]

9. Izar, B.; Rotow, J.; Gainor, J.; Clark, J.; Chabner, B. Pharmacokinetics, clinical indications, and resistance mechanisms in molecular targeted therapies in cancer. Pharmacol. Rev. 2013, 65, 1351-1395. [CrossRef]

10. Mattern, J. Drug resistance in cancer: A multifactorial problem. Anticancer Res. 2003, 23, 1769-1772.

11. Hotnog, D.; Mihaila, M.; Botezatu, A.; Matei, G.G.; Hotnog, C.; Anton, G.; Bostan, M.; Brasoveanu, L.I. Genistein potentiates the apoptotic effect of 5-fluorouracyl in colon cancer cell lines. Rom. Biotechnol. Lett 2013, 18, 8751-8760.

12. Housman, G.; Byler, S.; Heerboth, S.; Lapinska, K.; Longacre, M.; Snyder, N.; Sarkar, S. Drug resistance in cancer: An overview. Cancers 2014, 6, 1769-1792. [CrossRef]

13. Vanneman, M.; Dranoff, G. Combining immunotherapy and targeted therapies in cancer treatment. Nat. Rev. Cancer 2012, 12, 237-251. [CrossRef]

14. Holohan, C.; Van Schaeybroeck, S.; Longley, D.B.; Johnston, P.G. Cancer drug resistance: An evolving Paradigm. Nat. Rev. Cancer 2013, 13, 714-726. [CrossRef]

15. Ke, X.; Shen, L. Molecular targeted therapy of cancer: The progress and future prospect. Front. Lab. Med. 2017, 1, 69-75. [CrossRef]

16. Bergamo, A.; Stocco, G.; Gava, B.; Cocchietto, M.; Alessio, E.; Serli, B.; Iengo, E.; Sava, G. Distinct effects of dinuclear ruthenium(III) complexes on cell proliferation and on cell cycle regulation in human and murine tumor cell lines. JPET 2003, 305, 725-732. [CrossRef] [PubMed]

17. Adhireksan, Z.; Davey, G.E.; Campomanes, P.; Groess, M.; Clave, C.M.; Yu, H.; Nazarov, A.A.; Yeo, C.H.F.; Ang, W.H.; Dröge, P.; et al. Ligand substitutions between ruthenium-cymene compounds can control protein versus DNA targeting and anticancer activity. Nat. Commun. 2014, 5, 3462. [CrossRef] [PubMed]

18. Rocha, C.R.R.; Silva, M.M.; Quinet, A.; Cabral-Neto, J.B.; Menck, C.F.M. DNA repair pathways and cisplatin resistance: An intimate relationship. Clinics 2018, 73, e478s. [CrossRef] [PubMed]

19. Bostan, M.; Mihaila, M.; Petrica-Matei, G.G.; Radu, N.; Hainarosie, R.; Stefanescu, C.G.; Roman, V.; Diaconu, C.C. Resveratrol Modulation of Apoptosis and Cell Cycle Response to Cisplatin in Head and Neck Cancer Cell Lines. Int. J. Mol. Sci. 2021, 22, 6322. [CrossRef]

20. Zeng, L.; Chen, Y.; Liu, J.; Huang, H.; Guan, R.; Ji, L.; Chao, H. Ruthenium(II) complexes with 2-phenylimidazo[4,5-f][1,10]phenanthroline derivatives that strongly combat cisplatin-resistant tumor cells. Sci. Rep. 2016, 6, 19449. [CrossRef]

21. Silvestri, S.; Cirilli, I.; Marcheggiani, F.; Dludla, P.; Lupidi, P.; Pettinari, R.; Marchetti, F.; Di Nicola, C.; Falcioni, G.; Marchini, C.; et al. Evaluation of the anticancer role of a novel ruthenium(II)-based compound compared to NAMI-A and cisplatin in impairing mitochondrial functionality and promoting oxidative stress in triple negative breast cancer models. Mitocondrion 2021, 56, 25-34. [CrossRef]

22. Xu, L.; Zhong, N.J.; Xie, Y.Y.; Huang, H.L.; Jiang, G.B.; Liu, Y.J. Synthesis, characterization, in vitro cytotoxicity, and apoptosisinducing properties of ruthenium(III) complexes. PLoS ONE 2014, 9, e96082. [CrossRef]

23. Malecka, M.; Skocynska, A.; Goodman, D.M.; Hartinger, C.G.; Budzisz, E. Biological properties of ruthenium(II)/(III) complexes with flavonoids as ligands. Coord. Chem. Rev. 2021, 436, 213849. [CrossRef]

24. Uivarosi, V. Metal Complexes of Quinolone Antibiotics and Their Applications: An Update. Molecules 2013, $18,11153-11197$. [CrossRef]

25. Drlica, K.; Zhao, X. DNA gyrase, topoisomerase IV, and the 4-quinolones. Microbiol. Mol. Biol. Rev. 1997, 61, 377-392. [CrossRef]

26. Shen, L.L.; Chu, D.T.W. Type II DNA topoisomerases as antibacterial targets. Curr. Pharm. Des. 1996, 2, $195-208$.

27. Collin, F.; Karkare, S.; Maxwell, A. Exploiting bacterial DNA gyrase as a drug target: Current state and perspectives. Appl. Microbiol. Biotechnol. 2011, 92, 479-497. [CrossRef] [PubMed]

28. Anderson, V.E.; Osheroff, N. Type II topoisomerases as targets for quinolone antibacterials turning Dr. Jekyll into Mr. Hyde. Curr. Pharm. Des. 2001, 7, 337-353. [CrossRef] [PubMed]

29. Yadav, V.; Talwar, P. Repositioning of fluoroquinolones from antibiotic to anti-cancer agents: An underestimated truth. Biomed. Pharmacother. 2019, 111, 934-946. [CrossRef] [PubMed]

30. Ahmed, A.; Daneshtala, M. Nonclassical biological activities of quinolone derivatives. J. Pharm. Pharmaceut. Sci. 2012, 15, 52-72.

31. Hawtin, R.E.; Stockett, D.E.; Byl, J.A.W.; McDowell, R.S.; Tan, N.; Arkin, M.R.; Conroy, A.; Yang, W.; Osheroff, N.; Fox, J.A. Voreloxin Is an Anticancer Quinolone Derivative that Intercalates DNA and Poisons Topoisomerase II. PLoS ONE 2010, 5 , e10186. [CrossRef] 
32. Advani, R.H.; Hurwitz, H.I.; Gordon, M.S.; Ebbinghaus, S.W.; Mendelson, D.S.; Wakelee, H.A.; Hoch, U.; Silverman, J.A.; Havrilla, N.A.; Berman, C.J.; et al. Voreloxin, a first-in-class anticancer quinolone derivative, in Relapsed/Refractory solid tumors: A report on two dosing schedules. Clin. Canc. Res. 2010, 16, 2167-2175. [CrossRef]

33. Jamieson, G.C.; Fox, J.A.; Poi, M.; Strickland, S.A. Molecular and pharmacological properties of the anticancer quinolone derivative vosaroxin: A new therapeutic agent for acute myeloid leukemia. Drugs 2016, 76, 1245-1255. [CrossRef] [PubMed]

34. Marx, K.R.; Kantarjian, H.; Ravandi, F. Vosaroxin: Innovative anticancer quinolone for the treatment of acute myelogenous leukemia. Expert Opin. Orphan Drugs 2016, 4, 885-892. [CrossRef]

35. Sava, G.; Zorzet, S.; Turrin, C.; Vita, F.; Soranzo, M.; Zabucchi, G.; Cocchietto, M.; Bergamo, A.; DiGiovine, S.; Pezzoni, G.; et al. Dual action of NAMI-A in inhibition of solid tumor metastasis: Selective targeting of metastatic cells and binding to collagen. Clin. Cancer Res. 2003, 9, 1898-1905.

36. Jakupec, M.A.; Arion, V.B.; Kapitza, S.; Reisner, E.; Eichinger, A.; Pongratz, M.; Marian, B.; Graf von Keyserlingk, N.; Keppler, B.K. KP1019 (FFC14A) from bench to bedside: Preclinical and early clinical development-An overview. Int. J. Clin. Pharmacol. Ther. 2005, 43, 595-596. [CrossRef] [PubMed]

37. Reis, F.C.C.; Coelho, J.S.V.; Pazin, W.M.; Nikolaou, S. A newhomoleptic coordination compound of ruthenium and norfloxacin and its interaction with human serum albumin. Inorg. Chem. Commun. 2016, 63, 96-100. [CrossRef]

38. Tanimoto, M.K.; Dias, K.; Dovidauskas, S.; Nikolaou, S. Tuning the reaction products of ruthenium and ciprofloxacin for studies of DNA interactions. J. Coord. Chem. 2012, 65, 1504-1517. [CrossRef]

39. Alghamdi, M.T.; Alsibai, A.A.; Shahawi, M.S.; Refat, M.S. Synthesis and spectroscopic studies of levofloxacin uni-dentate complexes of $\mathrm{Ru}(\mathrm{II}), \mathrm{Pt}(\mathrm{IV})$ and $\mathrm{Ir}(\mathrm{III})$ : Third generation of quinolone antibiotic drug complexes. J. Mol. Liq. 2016, 224, 571-579. [CrossRef]

40. Alghamdi, M.T.; Alsibai, A.A.; Shahawi, M.S.; Refat, M.S. Structural and chelation behaviors of new Ru(II), Pt(IV) and Ir(III) gatifloxacin drug complexes: Spectroscopic characterizations. J. Mol. Struct. 2017, 1130, 264-275. [CrossRef]

41. Alibrahim, K.A.; Al-Saif, F.A.; Alghamdi, M.T.; El-Shahawi, M.S.; Moustafa, Y.M.; Refat, M.S. Synthesis, spectroscopic, thermal, antimicrobial and electrochemical characterization of some novel $\mathrm{Ru}(\mathrm{III}), \mathrm{Pt}(\mathrm{IV})$ and $\mathrm{Ir}(\mathrm{III})$ complexes of pipemidic acid. $R S C$ Adv . 2018, 8, 22515-22529. [CrossRef]

42. Badea, M.; Olar, R.; Marinescu, D.; Uivarosi, V.; Iacob, D. Thermal decomposition of some biologically active complexes of ruthenium (III) with quinolone derivatives. J. Therm. Anal. Calorim. 2009, 97, 735-739. [CrossRef]

43. Badea, M.; Olar, R.; Marinescu, D.; Uivarosi, V.; Nicolescu, T.O.; Iacob, D. Thermal study of some new quinolone ruthenium (III) complexes with potential cytostatic activity. J. Therm. Anal. Calorim. 2009, 99, 829-834. [CrossRef]

44. Arsene, A.L.; Uivarosi, V.; Mitrea, N.; Dragoi, C.; Nicolae, A. In vitro studies regarding the interactions of some novel ruthenium (III) complexes with double stranded calf thymus deoxyribonucleic acid (DNA). Farmacia 2016, 64, 712-716.

45. Arsene, A.L.; Uivarosi, V.; Mitrea, N.; Dragoi, C.; Nicolae, A. The binding properties of some novel ruthenium (III) complexes with human serum transferrin. Biopolym. Cell 2011, 27, 141-146. [CrossRef]

46. Uivarosi, V.; Olar, R.; Badea, M.; Chifiriuc, M.C. Antimicrobial activity of some new Ru(III) complexes with quinolone derivatives. Farmacia 2017, 65, 972-977.

47. Gruia, M.I.; Negoita, V.; Vasilescu, M.; Panait, M.; Gruia, I.; Velescu, B.S.; Uivarosi, V. Biochemical action of some new complexes of ruthenium with quinolones as potential antitumoral agents. Anticancer Res. 2015, 35, 3371-3378.

48. Munteanu, A.C.; Badea, M.; Olar, R.; Silvestro, L.; Mihaila, M.; Brasoveanu, L.I.; Musat, M.G.; Andries, A.; Uivarosi, V. Cytotoxicity studies, DNA interaction and protein binding of new $\mathrm{Al}(\mathrm{III}), \mathrm{Ga}(\mathrm{III})$ and $\mathrm{In}(\mathrm{III})$ complexes with 5-hydroxyflavone. Appl. Organomet. Chem. 2018, 32, e4579. [CrossRef]

49. Maciuca, A.M.; Munteanu, A.C.; Mihaila, M.; Badea, M.; Olar, R.; Nitulescu, G.M.; Munteanu, C.V.A.; Bostan, M.; Uivarosi, V. Rare-Earth Metal Complexes of the Antibacterial Drug Oxolinic Acid: Synthesis, Characterization, DNA/Protein Binding and Cytotoxicity Studies. Molecules 2020, 25, 5418. [CrossRef] [PubMed]

50. Munteanu, A.C.; Musat, M.G.; Mihaila, M.; Badea, M.; Olar, R.; Nitulescu, G.M.; Radulescu, F.S.; Brasoveanu, L.I.; Uivarosi, V. New heteroleptic lanthanide complexes as multimodal drugs: Cytotoxicity studies, apoptosis, cell cycle analysis, DNA interactions, and protein binding. Appl. Organomet. Chem. 2020, 35, e6062. [CrossRef]

51. Petrusca, D.N.; Petrescu, A.; Vrabie, C.; Jinga, V.; Diaconu, C.C.; Brasoveanu, L.I. Cell cycle regulatory factors in juxtatumoral renal parenchyma. Rom. J. Morphol. Embriol. 2005, 46, 117-122.

52. Mihaila, M.; Bostan, M.; Hotnog, D.; Ferdes, M.; Brasoveanu, L.I. Real-time analysis of quercetin, resveratrol and/or doxorubicin effects in MCF-7 cells. Rom. Biotechnol. Lett. 2013, 18, 8106-8114.

53. Hotnog, C.; Mihaila, M.; Panait, M.; Petrica-Matei, G.G.; Roman, V.; Gruia, M.I.; Bostan, M.; Brasoveanu, L.I. Resveratrol modulates oxidative stress as well as apoptosis in drug-treated SW1116 colon cancer cells. Rom. Arch. Microbiol. Immunol. 2017, $76,41-49$.

54. Petrica-Matei, G.G.; Roman, V.; Mihaila, M.; Hotnog, C.; Brasoveanu, L.I.; Bostan, M. Role of p38-mitogen-activated protein kinase in modulation of the response to therapy in FaDu human pharyngeal carcinoma cell line. Rom. Biotechnol. Lett. 2019, 24, 118-128. [CrossRef]

55. Bostan, M.; Petrica-Matei, G.G.; Ion, G.; Radu, N.; Mihaila, M.; Hainarosie, R.; Brasoveanu, L.I.; Roman, V.; Constantin, C.; Neagu, M.T. Cisplatin effect on head and neck squamous cell carcinoma cells is modulated by ERK1/2 protein kinases. Exp. Ther. Med. 2019, 18, 5041-5051. [CrossRef] 
56. Lacatusu, I.; Badea, N.; Badea, G.; Oprea, O.; Mihaila, M.A.; Kaya, D.A.; Stan, R.; Meghea, A. Lipid nanocarriers based on natural oils with high activity against oxygen free radicals and tumor cell proliferation. Mater. Sci. Eng. C 2015, 56, 88-94. [CrossRef]

57. Lacatusu, I.; Badea, N.; Badea, G.; Brasoveanu, L.; Stan, R.; Ott, C.; Oprea, O.; Meghea, A. Ivy leaves extract based-Lipid nanocarriers and their bioefficacy on antioxidant and antitumor activities. RSC Adv. 2016, 6, 77243-77255. [CrossRef]

58. Knop, C.; Putnik, J.; Scheuermann, M.; Schmitz, M. Cutting Edge Technologies: Cell Analysis; Ziebolz, B., Ed.; Springer Medizin: Heidelberg, Germany, 2010; pp. 4-13, 58-68, 137-141.

59. Teixeira, R.G.; Belisario, D.C.; Fontrodona, X.; Romero, I.; Tomaz, A.I.; Garcia, M.H.; Rigantib, C.; Valente, A. Unprecedented collateral sensitivity for cisplatin resistant lung cancer cells presented by new ruthenium organometallic compounds. Inorg. Chem. Front. 2021, 8, 1983-1996. [CrossRef]

60. Zimmermann, K.C.; Bonzon, C.; Green, D.R. The machinery of programmed cell death. Pharmacol. Ther. 2001, 92, 57-70. [CrossRef]

61. Townson, J.L.; Naumov, G.N.; Chambers, A.F. The role of apoptosis in tumor progression and metastasis. Curr. Mol. Med. 2003, 3, 631-642. [CrossRef] [PubMed]

62. Wong, R.S.Y. Apoptosis in cancer: From pathogenesis to treatment. J. Exp. Clin. Cancer Res. 2011, 30, 87. [CrossRef]

63. Su, Z.; Yang, Z.; Xu, Y.; Chen, Y.; Yu, Q. Apoptosis, autophagy, necroptosis, and cancer metastasis. Mol. Cancer 2015, 14, 1-14. [CrossRef]

64. Desoize, B.; Jardillier, J. Multicellular resistance: A paradigm for clinical resistance? Crit. Rev. Oncol. Hematol. 2000, 36, 193-207. [CrossRef]

65. Gillison, T.L.; Gurkamal, S.C. Cancer chemotherapy in the elderly patient. Oncology 2010, 24, 76-85. [PubMed]

66. Zhang, L.; Yu, J. Role of apoptosis in colon cancer biology, therapy, and prevention. Curr. Colorect. Cancer Rep. 2013, 9, 331-340. [CrossRef]

67. Bostan, M.; Mihaila, M.; Hotnog, C.; Bleotu, C.; Anton, G.; Roman, V.; Brasoveanu, L.I. Chapter Modulation of Apoptosis in Colon Cancer Cells by Bioactive Compounds. In Colorectal Cancer_From Pathogenesis to Treatment; Rodrigo, L., Ed.; Intech: Rijeka, Croatia, 2016.

68. Ucker, D.S.; Levine, J.S. Exploitation of apoptotic regulation in cancer. Front. Immunol. 2018, 9, 241. [CrossRef]

69. Pfeffer, C.M.; Singh, A.T.K. Apoptosis: A target for anticancer therapy. Int. J. Mol. Sci. 2018, 19, 448. [CrossRef]

70. Castillo Ferrer, C.; Berthenet, K.; Ichim, G. Apoptosis-Fueling the oncogenic fire. FEBS J. 2021, 288, 4445-4463. [CrossRef]

71. Kaufmann, S.H.; Vaux, D.L. Alterations in the apoptotic machinery and their potential role in anticancer drug resistance. Oncogene 2003, 22, 7414-7430. [CrossRef] [PubMed]

72. Volm, M.; Efferth, T. Prediction of cancer drug resistance and implications for personalized medicine. Front. Oncol. 2015, 5, 282. [CrossRef]

73. Wang, X.; Zhang, H.; Chen, X. Drug resistance and combating drug resistance in cancer. Cancer Drug Resist. 2019, 2, 141-160. [CrossRef] 